\title{
Effect of Devolution on the Performance of Human Resource Function in Health Sector in Kenya: The Case of Garissa County
}

\author{
Hassan Abdullahi Arale', Dr. Felix Kiruthu² \\ ${ }^{1}$ Correspondent Author, Student, Masters Degree in Public Policy and Administration at \\ Kenyatta University \\ ${ }^{2}$ Lecturer, Department of Public Policy and Administration, Kenyatta University
}

\section{ABSTRACT}

The declaration of a new constitution of Kenya on 31st August 2010 successfully made two levels of government; the national and county governments. Establishment of health services is one of the tasks that were devolved to the county. Devolution of health functions was meant to enhance access to more-fair and top-notch health services to the Kenyan citizens. This study sought to analyze the effect of devolution on human resource performance in healthcare sector in Kenya with special focus on Garissa County. The study specific objectives included to; examine how devolution has affected recruitment of health care staff in Garissa County; to analyze how devolution has affected training of health care staff in Garissa County. The study was guided by new public management theory. The study employed a descriptive research design to examine the effect of devolution on human resource performance in healthcare sector in Kenya. The target population was the healthcare workers with management portfolios and the sample population was 184 respondents which were arrived at using stratified sampling method. Both primary and secondary data were accessed. A questionnaire was used to collect primary data. Descriptive proportions of the respondents and their cadres were derived. Qualitative data was analyzed thematically, while quantitative data was analyzed using descriptive statistics and regression analysis. The findings were presented using tables and charts. The study found out that devolution has affected human resource performance in healthcare sector in Garissa County. The study established that lack of proper methods of recruitment of health care staff; lack of training of health care staff and application of ineffective methods of procurement of medical facilities hindered the performance of health care staff in the County. The study drew conclusion that the major effect of devolution on human resource performance in healthcare sector in Kenya; a case of Garissa County includes; recruitment of health care staff; training of health care staff and procurement of medical facilities. The study recommended that the County government should employ effective employee recruitment methods by hiring staff with technical expertise in health services delivery; the County government should also allocate and efficiently distribute enough financial resources to fund the recruitment exercise; the recruited staff should be better remunerated in order to improve their level of motivation and job satisfaction. The study further recommended that the County government should implement an effective and continuous employee training and development programmes on health care services delivery in the County. The County government should source and hire qualified doctors; employ enough and qualified nurses; hire enough and qualified support staff and give emphasis on hiring very experienced medical staff as lead trainers on health care services delivery in the County. The County government should adhere to all public procurement regulations in Kenya like public procurement and disposal act. The procurement methods should ensure that there is availability 
International Journal of Current Aspects, Volume 3, Issue III, 2019, PP 58-70, ISSN 2616-6976

[IJCAB

of medical facilities; there is a sufficient medical facility and there is high reliability of procured medical facilities in all regions in the County.

Keywords: Devolution, Human Resource Function, Staff Performance, Health Sector in Kenya

DOI 10.7176/ijcab.v3iIII.30, URN: nbn:de:0000ijcab.v3iIII.305

\section{Cite this Article:}

Arale, H., \& Kiruthu, F. (2019). Effect of Devolution on the Performance of Human Resource Function in Health Sector in Kenya: The Case of Garissa County. International Journal of Current Aspects, 3(III), http://journals.ijcab.org/journals/index.php/ijcab/article/view/30

\section{INTRODUCTION}

Devolution is one type of delegation and alludes to the exchange of public authority and resources including work force from national to sub national locale (Muia, 2008). Musgrave, (1959) and Oates, (1972) contend that devolution may enhance governance in the public service provision by enhancing the effectiveness of asset portion. Further, they watch that sub national governments are nearer to the general population than the focal government and accordingly have better learning about nearby inclination. Neighborhood administration is in this way better put to react to the differing needs of the nearby individuals. What's more, decentralization limits the social assorted variety and consequently the variety in local inclination, therefore prompting diminished conflicts among communities (Turin, 2010). Worldwide there appear to be a pattern in devolution of authority. As indicated by Agrawal and Ribot (2010), numerous nations have progressively adopted devolution as a system for administration and remedy institutional deficiencies that exceptionally concentrated governments have induced. These insufficiencies incorporate bureaucratic wasteful aspects, poor responsibility and straightforwardness, unequal dissemination of assets and low levels of group support in nearby improvement (Mills, 2008).

According to Mwamuye and Nyamu (2014), Kenya's healthcare devolution was meant to improve the quality of care services and efficiency in service delivery. However, it has since been confronting plenty of difficulties generally in light of the fact that healthcare workers (HCWs), who play a noteworthy role in accomplishing wellbeing targets, were dismissed amid execution. The world over, the healthcare sector is facing enormous, human resource challenges including financing, recruitment, development and maintenance of health care workers. Devolved government systems across the globe have and are experimenting with old as well as new approaches to manage their health workforce challenges as measure to improve on the quality of health care services delivery. In many Countries worldwide, in efforts to improve human resource aspect, various strategies have been designed such as changing staffing models, continuous staff training and adoption of effective procurement management methods. Devolved government systems have led to introduction of alternative health care delivery and operational model by decentralizing health care service from national to local control, and shifting the spectrum of care from hospitals to lower-cost settings. Accordingly, devolution has become one of the approaches that can help to improve human resource development among others such as care efficiency and cost effectiveness, and create new revenue opportunities for traditional health care providers and new market entrants (Phillip, 2012).

According to Shi and Sigingh (2011) devolution of political and administrative power is 
transforming into an irrefutably prevalent segment of health sector in all parts of the world, from Asia to Africa, from Europe to South America. This exchange of power away from the inside is regularly joined with a push to change an obsolete and common administration structure (Osur, 2013). Regardless of much commended decentralization, the worldwide lack of health specialists is evaluated at in excess of four million, expecting that all nations accomplish a normal laborer thickness of 2.5 for every 1,000 populace (counting only doctors, nurses, and midwives) (WHO, 2016). As indicated by the World Health Organization's World Health Report 2016, in light of information in the Global Atlas of the Health Workforce for 193 part states, there are as of now 57 nations including Kenya with basic deficiencies. These together have a deficiency of 2.4 million doctors, nurses, and midwives, with the corresponding shortages being most noteworthy in sub-Saharan Africa. To be sure sub-Saharan African nations should triple their present number of laborers if they are to accomplish the Sustainable Development Goals for health (Osur, 2013).

According to World Bank (2012) devolution has been identified as an approach to upgrade the proficiency of human services work force in social administration arrangement, considering a nearer coordinate between open strategies and the wants and needs of neighborhood voting public. Devolution helps in bringing government services nearer to residents, increases straightforwardness and empowers local citizens to closely monitor government activities (Olubulyera,. 2015). The constitution of Kenya (2010) characterizes devolution as the exchange of powers, duties, capacities and administrations (administration structures) from the national government to the county governments. According to Omolo, Kantai, and Wachira (2010) devolution allows County governments the freedom to come up with innovative forms of service delivery that suits their unique healthcare needs, an ample capacity to determine their health system priorities, and the power to make independent decisions. Garissa County already has a shortage of healthcare personnel and this is worsened by a high turnover of healthcare workers, a situation posing a major hindrance to health care service delivery in the County. For instance, the doctor population ratio is currently one doctor per 41,538 people and the nurse population ratio is one nurse per 2,543 people (Mwamuye and Nyamu, 2014).

Organization performance is an important building block of an organization that lays the foundation for high performance. This ensures that the organizations' goals are consistently being met in an effective and efficient manner (Anderson, 2008). There are several factors that affect performance of an organization. These include, personal characteristics including prior experience, confidence, heredity, ability and personality, standards set by line managers, motivation to perform, frequency of evaluation, teamwork and product knowledge (Bacal, 2011). Human resources are the most important resource in any organizations and the success of any business is the sum total of individual and collective organizational performance. Due to heightened competition for the most skilled and knowledgeable employees, it has increasingly become more difficult for employers to attract, retain, and motivate top talent from around the world needed for business to succeed(Chandrasekar, 2011).To enhance employee performance, employers must put measures in place to develop their staff so that they can think, work on their own and fulfil their responsibilities innovatively, while understanding, foreseeing the market and business situations(Gadot, 2007). Consequently a question arises about how benefits, learning and development, conducive work environment affect the performance of the organization (Makhamara, 2016).

Strategic human resource management researchers point to three mediators through which high performance work places - HWPS affect organizational performance. HPWPs operate by (a) 
increasing employee's knowledge, skills, and abilities (KSAs), (b) empowering employees to act, and (c) motivating them to do so (Becker \& Huselid, 2006). Broad recruiting and selectivity in staffing bring KSAs into organizations (Hoque, 2002). KSAs are further advanced through practices such as training, job design, and compensation tied to skill development (Canolly \& McGing, 2009). In the current study the human resource function was contextualized in terms of recruiting and training. Cohen and Pfeiffer (2006) argued that hiring standards reflect not only organizations' skill requirements but also the preferences of various groups for such standards and their ability to enforce these preferences and that a possible indirect link between selective hiring and organizational performance can be the forging of internal bonds between managers and employees that creates the right culture for productivity growth. Training programmes increase the firm specificity of employee skills which in turn increase employees' productivity and job dissatisfaction that results in employee turnover (Huselid, 2010). According to Omolo, Kantai and Wachira (2010), the scarcity of healthcare human resource workers is not unique to Kenya. In reality, Kenya is one of the nations recognized by the WHO as having a critical shortage of healthcare human resource personnel. As indicated by the health sector report (2013), Kenya had an average of 19 doctors and 173 nurses for every 100,000 populace, contrasted with WHO prescribed least staffing levels of 36 and 356 doctors and nurses respectively (Kibui, 2015). With respect to ideal staff foundation, the part would require 72,234 staff. Starting at 2012, the segment had an affirmed staff foundation of 59,667 however just around 49,096 positions were filled, leaving 10,371 positions vacant. This shortage was notably more regrettable in the Country zones where, as noted in ponder by Transparency International, (2011), under-staffing levels of in the vicinity of 50 and 80 for each penny were reported at provincial and rural health facilities (Waithaka,2013).

A study by Transparency International (2015), on effect of devolution on health care services management in County governments in Kenya revealed that only $21 \%$ (up from $18 \%$ in 2014) of Kenyans reported to be satisfied with the County governments' health management with 53\% (up from $51 \%$ in 2014) reporting being dissatisfied majorly due to non-visibility of service delivery as a result of devolution. In spite of these challenges, very little is documented on human resource policy implementation in the health care in Kenya particularly Garissa County (Waithaka, 2013). A study by Kinuthia (2016) on challenges facing devolution on performance of health care sector in Nakuru County identified that devolution has failed to achieve its goals on delivery of quality health care services since the county government failed to recruit experienced and competent health care staff and also the County government lacked the required medical equipments and facilities. Kinuthia (2016) study further established that lack of better remuneration packages for health care workers failed to attract trained health care staff and this led to deficiency in health care staff in terms of numbers and field of expertise. These negatively affected human resource performance in healthcare sector in the county leading to poor healthcare performance in the County.

A study by Tsofa (2017) on effect of devolution on performance of health care sector in Kilifi County established that devolution contributed too many challenges which affected the performance of the County health sector. Lack of required and qualified health care staff, poor recruitment of health care staff, and application of poor procurement procedures were identified as the key devolution challenges which affected the performance of health care sector in the County. Sofa (2017) further identified that lack of availability of enough and qualified nurses affected human resource performance in health sector. The study also noted that lack of 
availability of qualified support staff and lack of availability of experienced staff affected human resource performance in health sector in the County. Muchomba (2015) study on the effect devolved governance and performance of health sector in Kenya in Mombasa County identified that devolution had a major impact on the performance of the County health care sector. The study noted that devolution has affected recruitment of health care staff and the procurement of medical equipments and drugs. The study noted that there lacked staff with technical expertise in different medical fields and this made many patients who required specialized treatments to be referred to other hospitals outside the County. A study by Mutai (2015) on effect of devolution on procurement of health care supplies in Machakos County established that, application of ineffective procurement procedures which failed to adhere to public procurement and disposal act 2005 led to increased procurement costs and delay in delivery of medical equipments. These affected human resource performance in the County health sector since delay in procurement process affected availability of the required medical equipments in various County health care facilities. The study also noted that the employed recruitment procedures failed to attract very experienced and competitive health sector professionals in various medical fields. Kimathi (2017) did a study on the effect of devolution and human resource performance in Nyeri County health sector. The study identified that inadequate and lack of proper allocation of financial resources led to poor remuneration of medical personnel and this affected human resource performance in health sector. The study also established that lack of effective recruitment process of medical staff affected led to recruitment of unqualified and inexperienced staff and this hampered human resource performance in the County health sector.

\section{STATEMENT OF THE PROBLEM}

Analysis of the reviewed literature indicates that few studies have been undertaken on the effect of devolution on health care in Garissa County. Yet after devolution of healthcare services patients were reported to go without being attended to in public hospitals while some hospitals remained completely shut down thus posing health risks to thousands of Kenyans needing the service and scaring away potential investors thus posing a serious challenge to the sector. Onyango (2017) examined influence of talent management on employee retention in public hospitals in Kenya; a case of Siaya County Refferal Hospital and indicated that poor recruitment and employee training and development affected the service delivery within the hospital. Cherogony and Wapangana, (2017) conducted a study on an assessment of the role of working environment on performance of nurses in devolved health services in Baringo County, Kenya. The researchers noted that lack of a conducive environment that enables professional development of health workers negatively influenced their job performance. From the above studies there is a knowledge gap in that none of the research sought to examine how devolution of health services influences the human resource function influences within Garissa County hence the current study sought to fill the gap. The study examined how devolution has affected recruitment, training and facilities used by health personnel in Garissa County.

\section{OBJECTIVES OF THE STUDY}

The study was guided by the following specific objectives

i. To examine how devolution has affected recruitment of health care staff in Garissa County.

ii. To analyze how devolution has affected training of health care staff in Garissa County. 
iii. To determine how devolution has affected deployment of healthcare staff in Graissa County.

\section{THEORETICAL FRAMEWORK}

The study was guided by New Public Management Theory. New Public Management (NPM) is an approach to running public service organizations that is used in government and public service institutions and agencies, at both sub-national and national levels (Lane, 2002). The term was first introduced by academics in the UK and Australia to describe approaches that were developed during the 1980s as part of an effort to make the public service more "business-like" and to improve its efficiency by using private sector management models. The theory was first developed by Rondinelli and Cheema (1983) for assessing expansive procedures of decentralization in developing nations. This theory centers on the dissemination of health services inside a national political and authoritative structure. The investigation has a tendency to expect that people in general regulatory association is very incorporated and assembled at the Ministry of Health offices at the national level in the capital city. Accordingly, the model leads toward solutions about how to move duty and expert out from the inside to the outskirts of the administration framework. As with the private sector, which focuses on "customer service", NPM reforms often focused on the "centrality of citizens who were the recipient of the services or customers to the public sector." NPM reformers experimented with using decentralized service delivery models, to give local agencies more freedom in how they delivered programs or services (Dunleavy, Margetts, Bastow \& Tinkler, 2006). In some cases, NPM reforms that used e-government consolidated a program or service to a central location to reduce costs. Some governments tried using quasi-market structures, so that the public sector would have to compete against the private sector (notably in the UK, in health care). Key themes in NPM were financial control, value for money, increasing efficiency, identifying and setting targets and continuance monitoring of performance, handing over Power to the senior management executives. Performance was assessed with audits, benchmarks and performance evaluations. Some NPM reforms used private sector companies to deliver what were formerly public services (Maesschalck, 2004).

In NPM, citizens are viewed as customers and public servants are viewed as public managers and try to realign the relationship between public service managers and their political superiors by making a parallel relationship between the two. Under NPM, public managers have incentivebased motivation such as pay-for-performance, and clear performance targets are often set, which are assessed by using performance evaluations. As well, managers in an NPM paradigm may have greater discretion and freedom as to how they go about achieving the goals set for them (Maesschalck, 2004). This NPM approach is contrasted with the traditional public administration model, in which institutional decision-making, policy-making and public service delivery is guided by regulations, legislation and administrative procedures (Dunn, \& Miller, 2007). NPM has been cited as the solution for management ills in various organizational context and policy making in education and health care reform. NPM reforms use approaches such as disaggregation, customer satisfaction initiatives applying an entrepreneurial spirit to public service, and introducing innovations. The system allows "the expert manager to have a greater discretion. Public Managers under the New Public Management reforms can provide a range of choices from which customers can choose, including the right to opt out of the service delivery system completely" (Osborne, Radnor, \& Nasi, 2013). This theory centers around the institutional courses of action of decentralization and gives much direction to breaking down the 
capacities and undertakings that are exchanged starting with one institutional substance then onto the next and also distinguishing the scope of decision that is accessible to decision makers at each level. A great part of the exact writing utilizing this theory examines the need to determine exactly what errands or capacities are allocated to each shape or level as a structure giving explanatory instruments to indicate and analyze undertakings and capacities (Gilson, et. al. 1994). In this examination this theory bolsters the County top administration in enlistment and training of healthcare staff.

\section{CONCEPTUAL FRAMEWORK}

\section{Independent Variables}

\section{Dependent Variable}

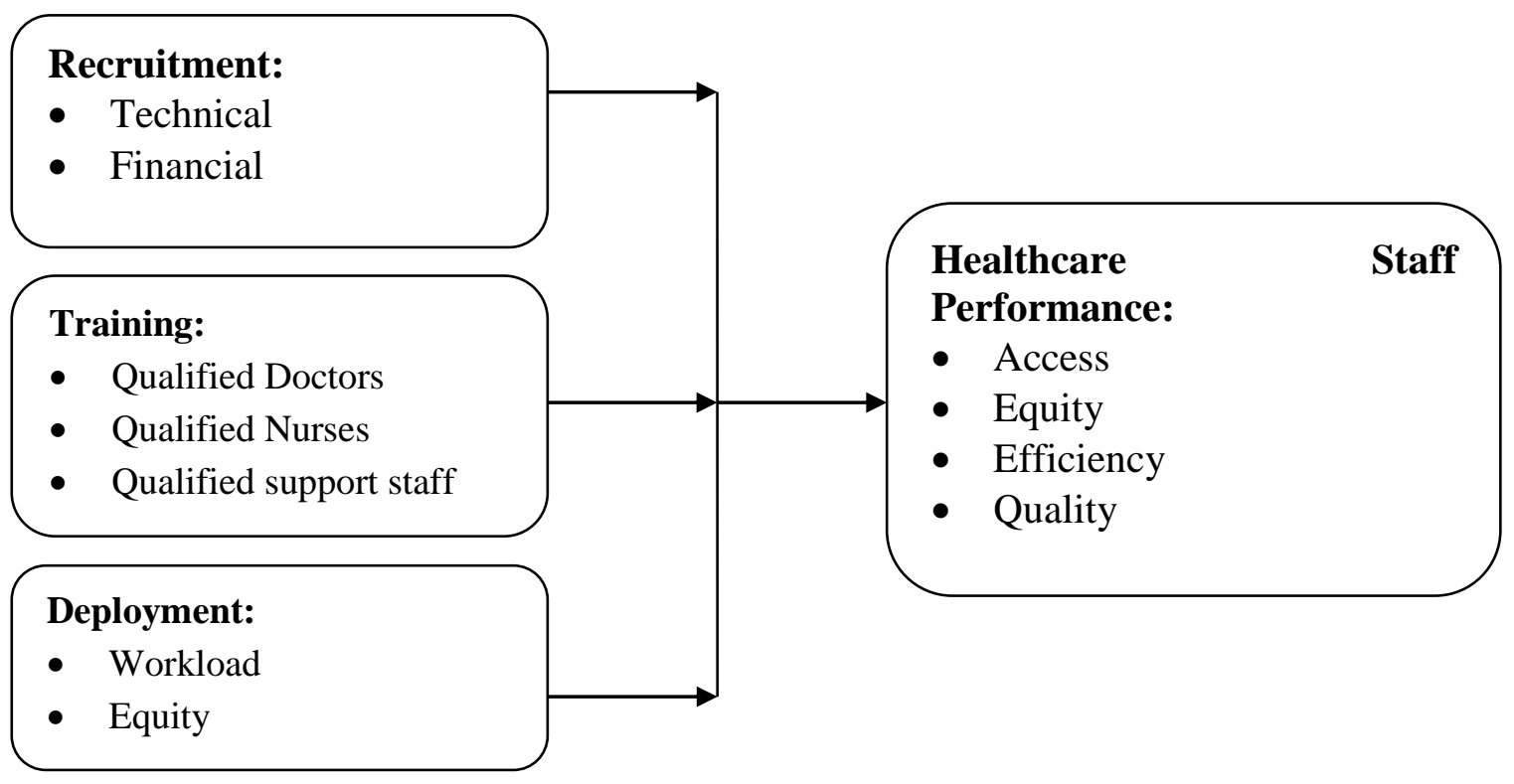

Figure 1: Conceptual Framework

The conceptual framework shows that the independent variables of the study include recruitment, training and resources. The dependent variable is health care staff performance. Employee recruitment is determined by availability of health care staff with technical skills and availability of financial resources to finance the recruitment process and fund health care staff remuneration budget. Training of health care staff determines the number of qualified doctors, qualified nurses and qualified support staff. All these determine the state of health care staff performance in terms of access, equity, efficacy and quality.

\section{RESEARCH METHODOLOGY}

Descriptive design was utilized in doing this examination to accomplish the objectives. The study was confined to Garissa County, one of the forty-seven Counties of the republic of Kenya provided in the Constitution of Kenya 2010. The study involved County health management team, Sub County management teams and facility management teams. The study was only centered on the ninety six functional service delivery points that include hospitals, health centers and dispensaries in the county. Garissa County is divided into six administrative sub-counties. The study involved county health management team, Sub county management teams and facility management teams. The study was only centered on the ninety six functional service delivery 
iJ $C A B$

points that include hospitals, health centers and dispensaries in the County; which formed the study unit of analysis. The target population for this study was all 184 healthcare staff in the county government of Garissa. For practical purposes however, the study considered those employees in management positions since they possess information relevant to the study. They comprised the county health management team, sub county health management team and facility health managers.

Stratified sampling method was used. There are 16 members at the county management level, 72 members at the sub-county management level and 96 at the facility management level making 184 health managers. To be able to choose participants for the study stratified proportionate sampling procedure was used in selecting the desired respondents with the required characteristics. The research further adopted a census sampling of the study respondents. This ensured there is equal representation among the study respondents. The sample respondents for the study were 184 personnel. The study collected both primary data. The primary Data was collected using questionnaires structured around the study objectives. Both open ended and closed ended questions were used. A structured questionnaire was preferred in this study because it provides an opportunity for the respondent to explain, and if possible, make further suggestions to the topic under study. Responses were estimated on an ordinal (Likert) scale for the closed ended. The researcher reviewed hospital reports, journals and other government publications as source of secondary data. Data collected using the self-administered questionnaire was coded, verified for completeness and accuracy and was analyzed using quantitative approached to derive descriptive statistics/outputs. The Statistical Package for Social Scientists (SPSS) was used for data analysis. Both inferential and descriptive statistics were used in analysis of the data.

\section{RESEARCH FINDINGS}

The study further carried out regression analysis to establish the statistical significance relationship between independent variables and dependent variables. The independent variables included $\left(\mathrm{X}_{1}\right)$ recruitment of health care staff; $\left(\mathrm{X}_{2}\right)$ training of health care staff while the dependent variable Y was human resource performance. According to Green \& Salkind (2003) Regression analysis helps in generating equation that describes the statistics relationship between one or more predictor variables and the response variable. The regression analysis results were presented using regression model summary table, Analysis Of Variance (ANOVA) table and beta coefficients table. In interpreting the results of multiple regression analysis, the three major elements considered were: the coefficient of multiple determinations, the standard error of estimate and the regression coefficients. $\mathrm{R}$ squared was used to check how well the model fitted the data. $\mathrm{R}$ squared is the proportion of variation in the dependent variable explained by the regression model. These elements and the results of multiple regression analysis were presented and interpreted accordingly in table 4.7, table 4.8 and table 4.9. From the findings in table 4.7, the regression model coefficient of determination (R2) is 0.557 and $R$ is 0.746 at 0.05 significance level.

This is an indication that the three independent variables notably; recruitment of health care staff; training of health care staff and procurement of medical facilities are significant in determining the dependent variables $\mathrm{Y}=$ human resource performance. Garissa County is affected by recruitment of health care staff; training of health care staff; procurement of medical facilities. The remaining $44.3 \%$ of the variation on human resource performance can be explained by other variables not included in the model. $44.3 \%$ implies that there are factors not studied in this study 
iJCAB

that affects human resource performance in the health sector. This shows that the model has a good fit since the value is above 50\%. This concurred with Graham (2002) that (R2) is always between 0 and 100\%: 0\% indicates that the model explains none of the variability of the response data around its mean and $100 \%$ indicates that the model explains all the variability of the response data around its mean. In general, the higher the (R2) the better the model fits the data.

Table 1: Regression Model Summary

\begin{tabular}{llllll}
\hline Model & $\mathrm{R}$ & $\mathrm{R}$ Square & $\begin{array}{l}\text { Adjusted } \\
\text { Square }\end{array}$ & $\mathrm{R}$ & $\begin{array}{l}\text { Std. Error of the } \\
\text { Estimate }\end{array}$ \\
\hline 1 & $.746(\mathrm{a})$ & .557 & .715 & .26295 &
\end{tabular}

Predictors: (Constant), Recruitment of staff, Training of Staff

The study further used one way Analysis of Variance (ANOVA) in order to test the significance of the overall regression model. Green \& Salkind (2003) posits that one way Analysis of Variance (ANOVA) test whether the model is important in predicting the significant effect of independent variable on dependent variable. From the results in table 4.8, 0.05 level of significance the ANOVA test indicated that in this model the independent variables namely; training of health care staff and recruitment of health staff are important in predicting human resource performance in health sector in Carissa County. as indicated by significance value $=0.000$ which is less than 0.05 level of significance $(\mathrm{p}=0.000<0.05)$. Therefore, there is significant relationship between independent variables and dependent variable. Table 2 also indicates that the high value of $F$ (105.683) with significant level of $p$-value 0.00 which is less than $5 \%$ level of significance is enough to conclude that all the independent variables significantly affect dependent variable. This implies goodness of fit of the model and thus the variables can be carried on for further analysis to determine with significance the level of influence of each variable.

\section{Table 2: Analysis of Variance (ANOVA)}

\begin{tabular}{|c|c|c|c|c|c|c|}
\hline Model & & $\begin{array}{l}\text { Sum } \\
\text { Squares }\end{array}$ & $\overline{\mathrm{df}}$ & Mean Square & $\bar{F}$ & Sig. \\
\hline \multirow[t]{3}{*}{1} & $\begin{array}{l}\text { Regressio } \\
\mathrm{n}\end{array}$ & 21.922 & 3 & 7.307 & 105.683 & $.000(a)$ \\
\hline & Residual & 8.435 & 122 & .069 & & \\
\hline & Total & 30.357 & 125 & & & \\
\hline
\end{tabular}

a. Predictors: (Constant), Training of staff, Recruitment of staff

b. Dependent Variable: Performance of human resource function

Table 3 further presents the results of the test of beta coefficients which shows the extent to which each independent variable affect human resource performance most in the health sector. From the findings in Table 4.9 above, at 5\% level of significance, recruitment of health care staff was a significant predictor of human resource performance where $(\mathrm{P}=0.000<0.05)$. Training of health care staff was also a significant predictor of human resource performance where $(\mathrm{P}=0.004<0.05)$. Where, $\mathrm{Y}$ is the dependent variable (human resource performance), $\left(\mathrm{X}_{1}\right)$ recruitment of health care staff and $\left(\mathrm{X}_{2}\right)$ training of health care staff. As per the SPSS generated regression Table 4.11 the regression equation was; 
$\left(\mathrm{Y}=\beta_{0}+\beta_{1} \mathrm{X}_{1}+\beta_{2} \mathrm{X}_{2}+\varepsilon\right)$ becomes:

$\mathrm{Y}=0.958+0.532 \mathrm{X}_{1}+0.106 \mathrm{X}_{2}$

This clearly demonstrates that all the independent variables significantly affected human resource performance in health sector in Garissa County but the relative importance of each independent variable is different. However, since the significance values were less than 0.005 , all the coefficients were significant.

\section{Table 3: Coefficients}

\begin{tabular}{|c|c|c|c|c|c|c|}
\hline \multirow[t]{2}{*}{ Model } & & \multicolumn{2}{|c|}{$\begin{array}{l}\text { Unstandardized } \\
\text { Coefficients }\end{array}$} & $\begin{array}{l}\text { Standardized } \\
\text { Coefficients }\end{array}$ & $\mathrm{t}$ & Sig. \\
\hline & & B & Std. Error & Beta & & \\
\hline \multirow[t]{3}{*}{1} & (Constant) & .958 & .215 & & 4.450 & .000 \\
\hline & $\mathrm{X} 1$ & .532 & .054 & .636 & 9.902 & .000 \\
\hline & $\mathrm{X} 2$ & .106 & .065 & .121 & 1.629 & .004 \\
\hline
\end{tabular}

a Dependent Variable: Performance of human resource function

A unit increase of recruitment of health care staff would lead to a 0.532 increase in human resource performance; a unit increase of training of health care staff would lead to a 0.106 increase in human resource performance and a unit increase of procurement of medical facilities would lead to a 0.160 increase in human resource performance. These findings thus imply that that recruitment of health care staff is the key factor that affects most human resource performance in the health sector most with a coefficient of 0.532 , , then lastly training of health care staff with a coefficient of 0.106. These findings are in agreement with findings by Agrawal and Ribot (2010) that recruitment of health care staff; training of health care staff are some of the major factors that affects the performance of health care staff in devolved government structures. These findings are further supported by Stephen and Bula (2017) who indicated that adoption of human resource practices such as recruitment and selection and employee training had a positive influence on the performance of referral hospitals in Kenya. K'osuri, Kalei, and Onyango (2018) also indicated that recruitment and training of employees had a positive effect on their performance of hospital within County Government.

\section{CONCLUSIONS}

The research concludes that devolution had a significant and positive effect on the human resource performance within the healthcare sector in Garissa County. The results of the study showed that $55.7 \%$ variations in the human resource performance were attributed to devolution. The study concludes that the County government should strengthen recruitment of personnel within the health sector by ensuring that the potential personnel have the relevant technical expertise, are within the laid remuneration levels and adequate resources are available for adding new employees. In regard to the training of health care staff the study concludes that hospitals should retain experienced staff and qualified ones to ensure there is better talent and knowledge retention within the hospital which is key to enhanced competency.

\section{RECOMMENDATIONS}

To improve on the recruitment of health care staff and improve human resource performance in healthcare sector in Garissa County, the County government should employ effective employee 
recruitment methods by hiring staff with technical expertise in health services delivery; the County government should also allocate and efficiently distribute enough financial resources to fund the recruitment exercise; the recruited staff should be better remunerated in order to improve their level of motivation and job satisfaction; the recruitment process should be open, fair and transparent conducted in accordance with the government human resource recruitment policies and deployment of staff should be done through equity and based on the workload on that station. The improve on training of health care staff and improve on human resource performance, the County government should implement an effective and continuous employee training and development programmes on health care services delivery in the County. The County government should source and hire qualified doctors; employ enough and qualified nurses; hire enough and qualified support staff and give emphasis on hiring very experienced medical staff as lead trainers on health care services delivery in the County. To improve on the process and criteria of deployment of health care staff the County government should consider the expertise needed for the position to serve, corresponding job group to the responsibility/ duties in all stations, considerations of age, gender, health and physical abilities and family considerations e.g. couples and populations to serve and finally incase of outbreaks there is need for personnel to contain the outbreak.

\section{REFERENCES}

Agrawal, A., \& Ribot, J. (2010). Accountability in Decentralisation: A Framework with South Asian and Africa Cases. The Journal of Development Areas, , No 33 pp 437-502.

Anderson, E. (2008). The usefulness of Performance Management in aligning individual and organizational goals for successful results, . Cole Audi-Academia.edu.

Bacal, R. (2011). Performance Management, 2nd Edition.

Becker, B., \& Huselid, M. (2006). High performance work system and firm performance. Personnel and Human Resources Management.

Canolly, P., \& McGing, G. (2009). High Performance Work Practices and competitive advantage in the Irish hospitality sector. . International Journal of contemporary hospitality management, , 19(3), $201-210$.

Chandrasekar, K. (2011). Workplace Environment and Its Impact on Organisational Performance in Public Sector Organisations.

Cherogony, E., \& Wapangana, M. M. (2017). An Assessment of the Role of Working Environment on Performance of Nurses in Devolved Health Services in Baringo County, Kenya. . International Journal of Innovative Research and Development, , 6(9).

Cohen, Y., \& Pfeffer, J. (2006). Determinants of Internal labor markets in organizations. . Administrative science Quarterly, , 29: 550-572.

Dunleavy, P., Margetts, H., Bastow, S., \& Tinkler, J. (2006). New public management is deadlong live digital-era governance. . Journal of public administration research and theory, , 16(3), 467-494.

Dunn, W. N., \& Miller, D. Y. (2007). A critique of the new public management and the neoWeberian state: advancing a critical theory of administrative reform. . Public organization review, , 7(4), 345-358.

Gadot, E. V. (2007). Human Resource Management. International Digest, , Vol. 13: Issue. 7.

Goverment of Kenya. (2010). Kenya Health Situation Analysis, Trends and Distribution, 1994 2010 and Projections to 2030. Nairobi: Ministry of Medical Services and Ministryof Public Health and Sanitation. 
International Journal of Current Aspects, Volume 3, Issue III, 2019, PP 58-70, ISSN 2616-6976

[IJCAB

Health Action Report. (2011). Health financing in Kenya: The case for Reproductive Health.

Hoque, K. (2002). Human resource management and performance in the UK hotel industry. . British Journal of Industrial Relations, , 37, 419-443.

Huselid, M. (2010). The impact of human resource management practices on turnover, productivity, and corporate financial performance,. Academy of Management Journal, , 38(3), 635-72.

K'osuri, M. A., Kalei, A., \& Onyango, R. (2018). Effect of Social Correlates on Employee Performance in Public Health Facilities, Turbo Sub County, Kenya. . International Journal of Multidisciplinary and Current research, 6.

Kenya National Bureau of standards. (2009). Kenya Demographic Health Survey.

Kimathi, E. (2017). Challenges of devolved health sector in Kenya. International Journal of Advanced Research, , Volume 2, Issue 4, 263-268.

Kinuthia, P. (2016). challenges facing devaluation in Kenya. International Journal of Advanced Research, , Volume 2, Issue 4, 263-268.

KMPDU. (2013). Health devolution In Kenya. N. airobi.: Kenya Medical, Pharmacists and Dentistry Union.

Lane, J. E. (2002). New public management: an introduction. Routledge.

Maesschalck, J. (2004). The impact of new public management reforms on public servants' ethics: Towards a theory. . Public administration, , 82(2), 465-489.

Makhamara, F. H. (2016). Influence of strategic recruitment and selection on employee performance in the health sector in Kenya. Strategic Journal of Business \& Change Management, 3(3).

Mills, A. (2008). Decentralization and Acountability in the Health Sector from an International Perspective. Public Administration and Development, , 789-804.

Mills, A. (2011). The Challenge of Health Sector Reforms: What Must Goverments Do?

Ministry of Health. (2013). Kenya Health Sector Strategic Plan Investment Plan (KHSSPI)July 2013- June 2017. . Nairobi: Republic of Kenya., .

Ministry of medical Services \& Ministry of Public health \& Sanitation. (2012). The draft KenyaHealth Sector Strategic \& Investment Plan (KHSSP) July 2012 - June 2018. . Nairobi: Ministry of medical Services \& Ministry of Public health \& Sanitation.

Ministry of Medical services \& Ministry of Public Health and Sanitation. (2012). Kenya HealthPolicy 2012-2030. . Nairobi: Goverment Printers.

Muchomba, T. (2015). effect devolved governance and performance of health sector in Kenya in Mombasa Conty. . International Journal of Advanced Research, , Volume 2, Issue 4, 263-268.

Muia, D. M. (2008). Devolution of Governance to Districts in Kenya: New Approches. Nairobi.

Musgrave, R. (1959). The Theory of Public Finance: A Study in Public Economy. . New York: McGraw-Hill.

Mutai, E. (2015). Devaluation in Kenya. . International Journal of Advanced Research, , Volume 2, Issue 4, 263-268.

Mwamuye, M. K., \& Nyamu, H. M. (2014). Devolution of Healthcare System in Kenya: A strategic approach and its implementation in Mombasa County, Kenya. . International Journal of Advanced Research, Volume 2, Issue 4, 263-268.

National Health Accounts. (2012). Health Financing. . Nairobi: Goverment Press.

NDHS. (2009). National Demogarphic Health Survey. Nairobi: Goverment Printer. 
International Journal of Current Aspects, Volume 3, Issue III, 2019, PP 58-70, ISSN 2616-6976

[IJCAB

Omolo, A., Kantai, W., \& achira, K. (2010). Devolution In Kenya: Prospect, Challenges and the Future. . Nairobi: Institute Of Economic Affairs.

Onyango, J. A., Cheluget, J. K., Akello, G. M., \& Okari, H. (2012). Factors to be Considered in Revenue Allocation to Devolved Government in Kenya. Prime Journals, , Vol 355: pp 704- 708.

Onyango, P. O. (2017). Influence Of Talent Management On Employee Retention In Public Hospitals In Kenya; A Case Of Siaya County Refferal Hospital. . Strategic Journal of Business \& Change Management, $4(2)$.

Osborne, S. P., Radnor, Z., \& Nasi, G. (2013). A new theory for public service management? Toward a (public) service-dominant approach. . The American Review of Public Administration, , 43(2), 135-158.

Osur, D. J. (2013). Effects of Devolution on Health Care . Nairobi: Daily Nation .

Rondinelli, D. (2010). Government Decentralization in Comparative Perspective: Theory and Practices in developing Countries. . Journal of International Review of Administrative Science, , 89: 267-319.

Stephen, S. O., \& Bula, H. (2017). Human Resource Management Practices and Quality of Health Care Service Delivery at Jaramogi Oginga Odinga Teaching and Referral Hospital, Kenya. . Human Resource Management, , 126-140.

Theo, L., Sauerborn, R., \& Bodart, C. (2000). Design and Implementation of Health. . Geneva: WHO.

Transparency International. (2011). The Kenya Health Sector Integrity Study Report. Nairobi.

Turin, D. R. (2010). Health Care Utilization in the Kenyan Health System: Challenges and Opportunities. Nairobi, Kenya.

United Nations Development Programme. (2010). Human Development Reports. Nairobi: United Nations.

Waithaka, W. (2013). Health Devolution in Kenya. . Nairobi: Kenya Medical Dentistry and Practitioners Board. .

WHO. (2006). Human Resource for Health. Geneva: World Health Organization.

WHO. (2010). Global Atlas of Health Workers. World Health Organisation.

World Bank. (2012). Devolution Without Disruption: Pathway to a successful Kenya . Nairobi: World Bank.

World Bank. (2012). Health Expenditure. . Nairobi:: Wolrdbank.

World Health Organisation. (2001). Report of the Scientific Peer Group on Health Systems Performance Assessment. . Geneva: World Health Organisation.

World Health Organisation. (2012). Country Health Profile. Kenya.

This is an open-access article published and distributed under the terms and conditions of the $(\mathrm{cc}) \mathrm{EY}$ Creative Commons Attribution 4.0 International License of United States unless otherwise stated. Access, citation and distribution of this article is allowed with full recognition of the authors and the source.

Authors seeking to publish with an International Peer Reviewed Journal should consider www.ijcab.org by writing to the Editor at editor@ijcab.org. 